\title{
Prospects of Problem-Based Learning in Building Critical Thinking Skills among Technical College Students in Nigeria
}

\author{
Sada, A. M ${ }^{1}$ \\ Mohd, Z. A 2 \\ Adnan $\mathrm{A}^{3}$ \\ Yusri $K^{4}$ \\ 1, 2.3.4 Department of Technical Vocational Education and training, Universiti Teknologi, Malaysia \\ Correspondent Email: sadamaigari67@yahoo.com
}

\author{
Doi:10.5901/mjss.2016.v7n3p356
}

\section{Abstract}

Critical-thinking skills (CTS) are among the essential skills required in the contemporary world of work. However, building CTS among technical college students in Nigeria is making little impact on students as current teaching uses is "traditional" rote learning methods which do not foster the building of skills. Therefore, a new teaching method is required that emphasizes learning, understanding, and measuring skills rather than rote learning. Educators unanimously agree that, CTS can be taught using different teaching methods including concept mapping, critical questioning workshops, and systematic literature reviews and to problem based learning (PBL). PBL is a student-centered, task-based instructional method in which the teacher serves as a facilitator. The paper adapted a library based work; the data were collected using textbooks, journals articles and internet search. The literatures reveal that; PBL is the best approach to build CTS, integrating it into all areas of learnings and to the student's entire life. In PBL, students demonstrate an enhanced ability to use CTS in their activities. Against this backdrop, the paper aim to outline the impact of PBL in building CTS among the technical colleges students. The paper recommends that, for the purpose of filling the CTS gap, technical colleges should equip their students with the required skills through the application of a superior teaching method such as PBL.

Keywords: Problem-Based Learning, Critical Thinking Skills, Technical College, Learning

\section{Introduction}

Technical colleges in Nigeria were purposely opened to train people to acquired and mastered knowledge and skills for their formal daily use (Edu, Ayang, \& Idaka, 2012) and also to meet country's employment needs of middle and medium manpower, but unfortunately, it is noted that the preparation of workers for today's industries in Nigeria is ineffective leading to high unemployment rate of TVET graduates together with short fall of human resources (Udofia, Ekpo, Nsa, \& Akpan, 2012; Uwaifo, 2009).

The world is rapidly changing and the growth of different occupations and enormous demands for high-skilled workers that make a four-year degree less valuable for gaining employment. In line with this, essential skills such as CTS need to be developed among students to prepare them for future careers such as technicians, engineers, and leaders (Beyth-Marom, Novik, \& Sloan, 1987; Masek, 2012). According to Q. Zhou, Huang, and Tian (2013), CTS are such an integral part of modern education that one cannot be separated from the other. CTS are an indispensable instrument in modern society, enables students to effectively face the challenges in building new ideas, making correct selections, and understanding the world around them (Miri, David, \& Uri, 2007; Shakirova, 2007; Snyder \& Snyder, 2008; ZOLLER, 2001; Zoller \& Pushkin, 2007). Furthermore, Snyder and Snyder (2008) posits that, CTS are learned skills and a product of education, training and practice that must be developed, practiced; and constantly integrated into the curriculum in order to engage students in active learning.

Employers today are focused on how to recruit better workers who possess not only technical (hard) skills, but also have critical thinking, problem solving, decision making and good reasoning skills among others (Audu, Kamin, Musta'amal, Saud, \& Hamid, 2014). To overcome these challenges, Miri et al. (2007); and Zoller et al. (2000) suggested that, CTS should be integrated into the students' training in order to serve as a catalyst toward the analysis of unfamiliar 
situations, where-by their methods of asking questions, problem-solving and decision-making capabilities will centered on a framework of rational thinking. Essential skill such as CTS can best be learned and taught in schools using active teaching methods (Awang \& Ramly, 2008; Profetto-McGrath, 2005).

The learners' lifelong needs and development of CTS cannot be met by traditional methods of teaching; therefore, there is a need for a shift from teacher-centered methods to more learner-centered methods that are designed to increase learners' engagement and learning participation. Accordingly, in the present-day development of the pedagogical approach, one new method that has been claimed to promote students' critical-thinking ability is the use of PBL (Masek, 2012). Therefore, moving to PBL as new learning and teaching approach is seen as a possible solution to this problem. The literature reveals that; PBL is effective in targeted learning domains, such as knowledge acquisition (Bilgin, Senocak, \& Sozbilir, 2009; Dehkordi \& Heydarnejad, 2008b), critical-thinking ability (Şendağ \& Odabaşı, 2009), and motivation (Martin, West, \& Bill, 2008). Many researchers have highlighted that; PBL can also promote deep approaches to learning instead of surface approaches and thereby increase institutional benefits (Biggs, 2003); improve active learning (De Graaff \& Cowdroy, 1997; Du, 2006); develops the criticality of learners (Savin-Baden, 2003); improve self-directed learning capability (Du, 2006; Hmelo \& Evensen, 2000); increase the consideration of interdisciplinary knowledge and skills (De Graaf \& Kolmos, 2003; Kjærsdam, 1994); it develops management, collaboration and communication skills (Du, 2006; Kolmos, 1996, 1999, 2002); it develops professional identity and responsibility development (Du, 2006; Evensen \& Hmelo-Silver, 2000; Hmelo \& Evensen, 2000; Kolmos, 2010); and improve the meaningfulness of learning (Du, 2006; Savin-Baden, 2000).

In addition, PBL enables students to develop and refine higher-order thinking skills, problem-solving skills, creative and critical-thinking, leadership skills and self-regulated learning habits, all of which are necessary qualities for effective performance in today's business world (Awang \& Ramly, 2008; Major \& Palmer, 2001; Savery, 2015; Savery et al., 2006). According to Ali (2010); Mansur, Kayastha, Makaju, and Dongol (2014); and Morales-Mann and Kaitell (2001) when students went through the PBL approach they developed the skills needed by contemporary employers. The ultimate goals of the PBL approach, according to Hearn and Hopper, (2008), is to foster the development of CTS through problem solving.

\section{Concept of Problem Based Learning and it is Effectiveness in Teaching and Learning}

PBL starts once students are challenged with an open-ended, ill-structured, authentic (real-world) problem and work in groups to classify learning needs and develop a possible answer, with teachers saved as guide rather than a leader (Prince \& Felder, 2006, 2009; Vikas Shinde \& Inamdar, 2014). According to Myers (2008) PBL is an instructional (and curricular) learner- centered approach that empowers learners to conduct research, integrate theory and practice, and apply knowledge and skills to develop a viable solution to a defined problem. PBL is also one of the active teaching methods popularly known as the "student-centered" method which has been embraced by a number of institutions of higher learning across the globe as a method of delivery including Denmark, Canada, Australia, and Singapore ( $\mathrm{L}$. Brodie \& Gibbings, 2007; Kolmos et al., 2007; J. Wang, Fong, \& Alwis, 2005). PBL has been used in different educational disciplines, including chemical engineering (Xiuping, 2002; Zhang, 2002), electronic engineering (Mantri, 2014; Mantri, Dutt, Gupta, \& Chitkara, 2009), electrical engineering (Noordin, Nasir, Ali, \& Nordin, 2011), engineering and surveying (L. Brodie \& Gibbings, 2007), science education (K. K. H. Wong \& Day, 2009), mathematics (Bottge, Rueda, LaRoque, Serlin, \& Kwon, 2007), business and entrepreneurs (Mossuto, 2009), as well as agriculture (Anderson, 2007; Burris \& Garton, 2007).

The PBL approach involves important, contextualised, real-world answers and providing resources, guidance, and instruction to learners as they develop content knowledge and problem-solving skills (Mossuto, 2009). Duch, Groh, and Allen (2001b); Duch, Groh, and Allen (2001a) claim that; PBL is a pedagogical strategy that challenges students to "learn to learn', as they are working cooperatively in a small groups to find answers to real-world problems. It is generally accepted that PBL makes students to think critically and analytically, and also to seek and use suitable learning resources (Duch et al., 2001a, 2001b). Researches were conducted around the globe in all aspects of educational endeavours to ascertain the effectiveness of PBL in building skills among learners (Barsky, Catanach Jr, \& Stout, 2002; Braun, 2004; P. Brodie \& Irving, 2007; Celuch \& Slama, 1999; Gürses, Açıkyıldız, Doğar, \& Sözbilir, 2007; Kumar \& Natarajan, 2007; Masek \& Yamin, 2012; Saraoglu, Yobaccio, \& Louton, 2000; Snyder \& Snyder, 2008), and all the results demonstrate were in favour of effectiveness PBL in CTS building.

The literature reviewed for this article, it reveals that good PBL approaches requires effort in three domains: planning (identifying course content and defining measurable learning objectives for it); instruction (selecting and implementing the methods that will be used to deliver the specified content and facilitate learner achievement of the 
objectives); and assessment and evaluation (selecting and implementing the methods that will be used to determine whether and how well the objectives have been achieved and interpreting the results) (Felder \& Brent, 2003). These domains are illustrated in figure 1.

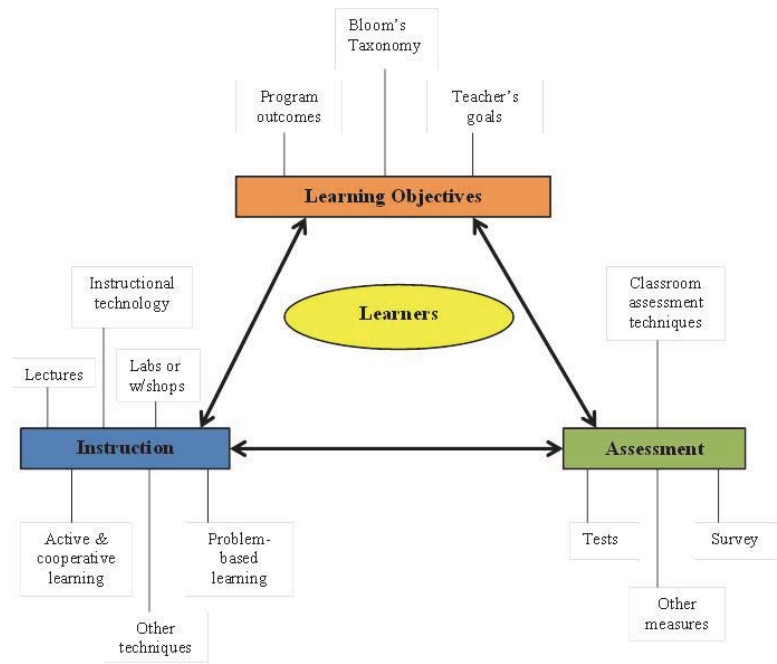

Figure 1: Elements of PBL course design

Source: (Felder \& Brent, 2003)

\section{Concept of Critical Thinking}

Critical thinking is a purposeful, self-regulatory judgment which results in interpretation, analysis, evaluation, and inference, as well as an explanation of the evidential, conceptual, methodological, criteriological, or contextual considerations upon which that judgment is based (Mulnix, 2012; Stewart, Cartier, \& Passmore, 2005; Q. Zhou et al., 2013). Similarly, critical thinking is seen as a process of evaluating evidence for certain claims, determining whether presented conclusions logically follow from the evidence, and considering alternative explanations (Fani, 2011). Accordingly, critical thinking will make students move "sideways" to try different perceptions, different concepts, and different points of entry (Awang \& Ramly, 2008).

Furthermore, critical thinking is viewed as one of the higher cognitive abilities, besides creative thinking, problemsolving, and decision-making (Colucciello, 1999; Daley, Shaw, Balistrieri, Glasenapp, \& Piacentine, 1999). Bailin and Siegel (2003); Bailin (2002); and Bailin (1987) posits that critical and creative thinking are closely linked and incorporated in producing effective thinking and problem-solving capabilities.

Learning and teaching higher-order cognitive abilities such as critical thinking has continuously been the ultimate goal of education (Spendlove, 2008), specifically in technology and engineering education. Paul and Scriven (2007), are of the opinion that critical thinking is similar to the scientific method; in that it is a methodical and technical means to understand and teach the process of thinking. Just as students learn the process of the scientific method, they must also learn the process of thinking critically. With the current development in manufacturing industries, building CTS among technical vocational education and training (TVET) students has becomes an imperative, if we want to have capable engineers for tomorrow (Norris, 1985, 1989); teaching CTS is believed to be as significant as educating a person (Masek \& Yamin, 2012).

\section{The Need to Build Critical Thinking Skills among Technical College Students in Nigeria}

Evidence from research has shown that there is the need to develop CTS among students world over. This is because many of them are not using sophisticated reasoning to solve problems even at the college level (Halpern, 1998, 1999, 2002; Kuhn, 1999, 2000; Marin \& Halpern, 2011; Miri et al., 2007; Ten Dam \& Volman, 2004; YILMAZ, 2013). It is 
unanimously accepted that CTS is becoming an important tool and key to success in modern societies, the world is developing rapidly, becoming more sophisticated in terms of IT and interdependencies continues to strengthen. Therefore, more critical thinkers are needed to make coherent decisions based-on evaluative and critical thinking rather than acceptance of precedent and authority (Beyth-Marom et al., 1987; Marin \& Halpern, 2011; Snyder \& Snyder, 2008). In the modern societies, people are expected to take responsibility and improve their own conditions rather than knowing their place (Ten Dam \& Volman, 2004).

In the Nigerian context, the literature reveals a worrisome situation (Egbo, 2011) in which Nigerian students are completely absent in international examinations like "Trends in International Mathematics and Science Study" and "Progress in Reading Literacy Study". This further signifies that, Nigerian students are not receiving the type of education that will prepare them for life in a competitive world that demands innovation, creativity and critical thinking. In addition, the quality of technical college graduates has been a major source of concern among most employers in the Nigerian labour market, who have expressed their dissatisfaction regarding the level of technical and essential skills possessed by the graduates (Inti, Latib, \& Rufai; Isah Usman, Celement, \& Raihan, 2013; Udofia et al., 2012). It is also reported in Nigeria that most of the TVET graduates do not perform well in jobs interviews because they only have general and theoretical knowledge that does little to prepare them for the actual tasks or skills they will encounter in their jobs (Isah Usman et al., 2013; Udofia et al., 2012; Umunadi, 2012), while most companies are looking for TVET graduates with skills beyond the standard paper degree (Agus, Awang, Yussof, \& Mohamed Makhbul, 2011; Beder, 2000; A. L. Brown \& Campione, 2002; Daud, 2013; Goddard, 2002; Goold \& Augar, 2009; Isah Usman et al., 2013; Ismail, Yussof, \& Sieng, 2011; Young \& Chapman, 2010).

The trend in the methods of teaching TVET programs in Nigerian technical and vocational colleges is still "traditional" and these are the kinds of methods which tend to hinder trainees from acquiring effective skills that make them to be self-reliant or employable (Akpomi, 2009; Eke, 2011; Garba, 2010; Kennedy, 2011).This explains why youth unemployment in Nigeria, appears to be increasing quickly, because many of them lack employability skills such as CTS. Even though, CTS is among those skills that are supposed to be acquired from technical colleges (Onu, 2013). The poverty level in Nigeria is 70\% despite TVET (Adebayo, 2013; Ajufo, 2013; Margwa, Onu, Jalo, \& Dire, 2015). Report shows that in 2003, primary school graduates accounted for $14.7 \%$ of unemployment, secondary school graduates constituted $53.6 \%$, and tertiary schools graduates constituted $12.4 \%$. In 2003 , the nation's poverty levels were put at $70 \%$ and more than 91 million Nigerians are said to live on less than one dollar per day (Ajufo, 2013).

Most analysts agree that contemporary employers demand more skilled workers than they did in the past (BeharHorenstein \& Niu, 2011; Bowell \& Kingsbury, 2013; Twiname \& Gibb, 2012). Therefore, building CTS among Nigeria's TVET students cannot be overemphasized. According to (Angelo, 1995) and (Duron, Limbach, \& Waugh, 2006) it is importance build CTS among TVET students in order to develop and improve the students'

- Ability to work productively with others,

- management skills, leadership skills,

- a commitment to accurate work,

- ability to follow directions,

- instructions, and plans,

- ability to organize and use time effectively,

- a commitment to personal achievement, and ability to perform skillfully.

In addition, Q. Wang, Woo, and Zhao (2009); C. Zhou (2012); and Kerka (1992) agreed that CTS is needed to be in cooperated into TVET training because, in this new knowledge era, the industries contains more complicated and sophisticated high-tech equipment and computerized systems, which create more complex problems that are more reliant on cognitive capabilities to solve. Therefore, it becomes crucial for career and technology educators to be more pragmatic, resourceful, creative, and flexible in their curriculum and delivery approaches if they are to provide students with the critical thinking and problem- solving skills they require in order to compete successfully for jobs in both the national and international work arenas (D. F. Brown, 2006).

\section{Problem-Based Learning and the Building of Critical Thinking Skills}

In a wider educational context, the number of studies that reported PBL as being less effective (Cinar \& Bayraktar, 2014; Matthews, 2004) is fairly equal to the number of studies reporting PBL provides a more effective construction of learners' knowledge acquisition of procedures or applications (Capon \& Kuhn, 2004; Dehkordi \& Heydarnejad, 2008a; Kasai, Sugimoto, \& Uchiyama, 2006; Pease \& Kuhn, 2011). When compared to Bloom's taxonomy of the cognitive domain, PBL 
appears to be effective in promoting learning at a higher cognitive level for application and evaluation, but not at the understanding level (Alcázar \& Fitzgerald, 2005; Dehkordi \& Heydarnejad, 2008a). Relating PBL to higher order thinking skill components, several studies that are related to PBL and CTS have showed positive outcomes (Atkinson, Derry, Renkl, \& Wortham, 2000; Iwaoka, Li, \& Rhee, 2010; Tiwari, Lai, So, \& Yuen, 2006). Moreover, (V Shinde, 2011; V. V. Shinde \& Inamdar, 2013) reported that PBL could be a suitable option for acquiring the skills needed by the industries. The result of that study mapped out PBL outcomes with skills gaps among Indian engineering graduates as requested by the industries. Table 1.1 summarizes the skills that can be achieved by learners in a PBL setting according to (V Shinde, 2011). The ' $X$ ' indicates that the skills can be achieved in the PBL environment.

Table 1.1: Alignment of skills demanded by employers and PBL learning outcomes

\begin{tabular}{|c|c|c|c|c|c|}
\hline $\begin{array}{l}\text { Core Employability } \\
\text { Skills gaps }\end{array}$ & $\begin{array}{l}\text { Learning outcomes } \\
\text { achievable by PBL }\end{array}$ & $\begin{array}{l}\text { Professional } \\
\text { Skills gaps }\end{array}$ & $\begin{array}{l}\text { Learning outcomes } \\
\text { achievable by PBL }\end{array}$ & $\begin{array}{l}\text { Communication } \\
\text { Skills gaps }\end{array}$ & $\begin{array}{l}\text { Learning outcomes } \\
\text { achievable by PBL }\end{array}$ \\
\hline Reliability & & Problem solving & $x$ & $\begin{array}{l}\text { Experiments/data } \\
\text { analysis }\end{array}$ & $x$ \\
\hline Self-motivated & $\mathrm{X}$ & Creativity & $X$ & Reading & $X$ \\
\hline Willingness to learn & $x$ & $\begin{array}{l}\text { Use of modern } \\
\text { tools }\end{array}$ & $x$ & Technical Skills & $x$ \\
\hline $\begin{array}{l}\text { Understand/take } \\
\text { directions }\end{array}$ & & $\begin{array}{l}\text { System design to } \\
\text { needs }\end{array}$ & & $\begin{array}{l}\text { Written } \\
\text { Communication }\end{array}$ & $x$ \\
\hline Integrity & & $\begin{array}{l}\text { Contemporary } \\
\text { issues }\end{array}$ & $X$ & $\begin{array}{l}\text { Verbal } \\
\text { Communication }\end{array}$ & $x$ \\
\hline Teamwork & $\mathrm{X}$ & $\begin{array}{l}\text { Apply } \\
\text { Math/Sci/Engg } \\
\text { know }\end{array}$ & & Advanced Computer & $x$ \\
\hline Entrepreneurship & & Customer Service & & Basic Computer & $x$ \\
\hline Self-discipline & $\mathrm{X}$ & & & $\begin{array}{l}\text { Communication in } \\
\text { English }\end{array}$ & $x$ \\
\hline \multicolumn{6}{|l|}{ Flexibility } \\
\hline Empathy & $X$ & & & & \\
\hline
\end{tabular}

Source: (V Shinde, 2011)

From the table it can be seen that the PBL approach, most of the skills needed by the employers can be achieved. This in turn can help to bridge the gap between employers' expectations and learning achieved at the technical institutes.

However, several studies also revealed negative outcomes, showing no significant difference from the two comparison groups, when investigating the effects of PBL on CT (Al Huthali, 2014; Ansari, Rahman, Badgujar, Sami, \& Abdullah, 2015; Hung, Jonassen, \& Liu, 2008; Mohammed Lame, Yusoff, \& Fauziah, 2013) reported that there is no significant differences between the compared groups involved. Furthermore, most of the studies on CT were conducted in the field of mathematics (Bahar, 2013; Chiu, 2009; Leikin, 2009). The studies that investigated the correlation between PBL and CT across disciplines and populations were insufficient (Tan, Chye, \& Teo, 2009; C. Zhou, 2012).

Though from the literature review, some research recorded negative results of either no significant difference or no difference at all between the study groups when researching the effectiveness of PBL on CTS building. Yet there is much other research that reported positive impact of PBL on the building of CTS which shows that the chances of PBL approach in building CTS among TVET students is higher if properly implemented. This is because, from the literature synthesis, it can be established that the PBL environment is favourable to improving students 'cognitive skills. The PBL approach has been recognized as an active agent in developing students' technical or cognitive skills like problemsolving, critical and creative thinking and application of knowledge, as well as process skills like project and time management, teamwork and leadership, written and oral language. Linking these results with Nigerian industries' needed essential skills, the importance of PBL for the Nigerian situation could be recognized. This is supported by Snyder and Snyder (2008); Duplass and Ziedler (2002); Hemming (2000); and M. S. Wong (2007), who stated that PBL should be used to develop CTS into the students.

\section{Conclusion}

In the present economy, where knowledge, information, customer service, innovation and high performance are the top priorities, the possession of CTS is becoming indispensable in order to gain employment and make career progression. 
Today's TVET students need to have diversity of skills that provide flexibility for them to be adaptable in the workforce. And in order to meet with these requirements, students would need "a firm institution of knowledge, skills and understanding. These are the skills that can be developed throughout each individual's lifetime and can be acquired at colleges through students' participation in the teaching and learning processes such as through the PBL approach.

\section{References}

Adebayo, A. A. (2013). Youths' unemployment and crime in Nigeria: A nexus and implications for national development. International Journal of Sociology and Anthropology, 5(9), 350. DOI: 10.5897/IJSA2013.0452

Agus, A., Awang, A. H., Yussof, I., \& Mohamed Makhbul, Z. (2011). The gap analysis of graduate employees' work skills in Malaysia. Proceedings of Business and Information, 8, 15.

Ajufo, B. I. (2013). Challenges of youth unemployment in Nigeria: Effective career guidance as a panacea. African Research Review, 7(1), 307-321. DOI: http://dx.doi.org/10.4314/afrrev.v7i1.21

Akpomi, M. E. (2009). Achieving millennium development goals (MDGs) through teaching entrepreneurship education in Nigeria higher education institutions (HEIS). European Journal of social sciences, 8(1), 152-159.

Al Huthali, M. (2014). Meaning-Making in an Engineering Problem-Based Learning Classroom: an Analysis of Activity and Multimodality. Victoria University. http://vuir.vu.edu.au/id/eprint/25849

Alcázar, M. M., \& Fitzgerald, V. L. (2005). An Experimental Design to Study the Effectiveness of PBL in Higher Education. First Year Science Students at a University in Peru, South America. College Quarterly, 8(2).

Ali, A. (2010). The effect of critical thinking dispositions on students achievement in selection and placement exam for university in Turkey. Journal of Turkish Science Education, 7(1), 61.

Anderson, J. C. (2007). Effect of problem-based learning on knowledge acquisition, knowledge retention, and critical thinking ability of agriculture students in urban schools. University of Missouri--Columbia. http://hdl.handle.net/10355/4832

Angelo, T. A. (1995). Classroom assessment for critical thinking. Teaching of psychology, 22(1), 6-7. DOI:10.1207/s15328023top2201_1

Ansari, M. T., Rahman, S. A., Badgujar, V. B., Sami, F., \& Abdullah, M. S. (2015). Problem Based Learning (PBL): A Novel and Effective Tool of Teaching and Learning. INDIAN JOURNAL OF PHARMACEUTICAL EDUCATION AND RESEARCH, 49(4), 258-265. DOI: 10.5530/ijper.49.4.3

Atkinson, R. K., Derry, S. J., Renkl, A., \& Wortham, D. (2000). Learning from examples: Instructional principles from the worked examples research. Review of educational research, 70(2), 181-214. doi: 10.3102/00346543070002181

Audu, R., Kamin, Y. B., Musta'amal, A. H. B., Saud, M. S. B., \& Hamid, M. Z. A. (2014). Perception of Teachers and Administrators on the Teaching Methods that Influence the Acquisition of Generic Skills. International Education Studies, 7(11), 40. doi:10.5539/ies.v7n11p40

Awang, H., \& Ramly, I. (2008). Creative thinking skill approach through problem-based learning: Pedagogy and practice in the engineering classroom. International Journal of Human and Social Sciences, 3(1), 18-23.

Bahar, A. (2013). The Influence of Cognitive Abilities on Mathematical Problem Solving Performance. http://hdl.handle.net/10150/293594

Bailin, S. (1987). Critical and creative thinking. Informal logic, 9(1).

Bailin, S. (2002). Critical thinking and science education. Science \& Education, 11(4), 361-375. DOI

10.1023/A:1016042608621

Bailin, S., \& Siegel, H. (2003). Critical thinking. The Blackwell guide to the philosophy of education, 181-193.

Barsky, N. P., Catanach Jr, A. H., \& Stout, D. E. (2002). A PBL framework for introductory management accounting Educational Innovation in Economics and Business (pp. 3-19): Springer. DOI

10.1007/978-94-017-1392-4_1

Beder, S. (2000). Valuable skills learned from "basket weaving". Engineers Australia, 46.

Behar-Horenstein, L. S., \& Niu, L. (2011). Teaching critical thinking skills in higher education: A review of the literature. Journal of college teaching and learning, 8(2), 25.

Beyth-Marom, R., Novik, R., \& Sloan, M. (1987). Enhancing children's thinking skills: an instructional model for decision-making under certainty. Instructional Science, 16(3), 215-231. DOI: 10.1007/BF00120251

Biggs, J. (2003). Aligning teaching and assessing to course objectives. Teaching and Learning in Higher Education: New Trends and Innovations, 2, 13-17.

Bilgin, I., Senocak, E., \& Sozbilir, M. (2009). The effects of problem-based learning instruction on university students' performance of conceptual and quantitative problems in gas concepts. Eurasia Journal of Mathematics, Science \& Technology Education, 5(2), 153-164.

Bottge, B. A., Rueda, E., LaRoque, P. T., Serlin, R. C., \& Kwon, J. (2007). Integrating Reform-Oriented Math Instruction in Special Education Settings. Learning Disabilities Research \& Practice, 22(2), 96-109. DOI: 10.1111/j.1540-5826.2007.00234.x

Bowell, T., \& Kingsbury, J. (2013). Critical thinking and the argumentational and epistemic virtues.

Braun, N. M. (2004). Critical thinking in the business curriculum. Journal of Education for Business, 79(4), 232.

Brodie, L., \& Gibbings, P. (2007). Developing problem based learning communities in virtual space. Paper presented at the ConnectED 2007: International Conference on Design Education. http://eprints.usq.edu.au/id/eprint/3027

Brodie, P., \& Irving, K. (2007). Assessment in work-based learning: investigating a pedagogical approach to enhance student learning. Assessment \& Evaluation in Higher Education, 32(1), 11-19. DOI:10.1080/02602930600848218 
Brown, A. L., \& Campione, J. C. (2002). Communities of learning and thinking, or a context by any other name. Contemporary issues in teaching and learning, 120-126.

Brown, D. F. (2006). It's the Curriculum, Stupid: There's Something Wrong with It: Educators, Parents, and Employers All Seem to Agree on the Types of Skills They Believe Students Should Be Developing. but Mr. Brown Finds That the Traditional Curriculum, Divided Up into Separate Subjects, Neither Engages Students nor Prepares Them for Productive Lives. He Believes That the Answer to Both Problems Is to Have Students Design Their Own Curricula. Phi Delta Kappan, 87(10), 777.

Burris, S., \& Garton, B. L. (2007). Effect of Instructional Strategy on Critical Thinking and Content Knowledge: Using Problem-Based Learning in the Secondary Classroom. Journal of Agricultural education, 48(1), 106-116.

Capon, N., \& Kuhn, D. (2004). What's so good about problem-based learning? Cognition and Instruction, 22(1), 61-79. DOI:10.1207/s1532690Xci2201_3

Celuch, K., \& Slama, M. (1999). Teaching critical thinking skills for the 21st century: An advertising principles case study. Journal of Education for Business, 74(3), 134-139. DOI:10.1080/08832329909601675

Chiu, M.-S. (2009). Approaches to the teaching of creative and non-creative mathematical problems. International Journal of Science and mathematics education, 7(1), 55-79. DOI:10.1007/s10763-007-9112-9

Cinar, D., \& Bayraktar, S. (2014). The effects of the problem based learning approach on higher order thinking skills in elementary science education. XIV IOSTE, 279.

Colucciello, M. L. (1999). Relationships between critical thinking dispositions and learning styles. Journal of Professional Nursing, 15(5), 294-301. doi:10.1016/S8755-7223(99)80055-6

Daley, B. J., Shaw, C. A., Balistrieri, T., Glasenapp, K., \& Piacentine, L. (1999). Concept maps: A strategy to teach and evaluate critical thinking. Journal of Nursing Education, 38(1), 42-47. DOI: 10.3928/0148-4834-19990101-12

Daud, M. (2013). How effective is the assessment of generic skills gained by Technical Vocational Education and Training (TVET) of engineering students engaged in Problem-Based Learning (PBL)?-A Literature Review. PBL Across Cultures, 88.

De Graaf, E., \& Kolmos, A. (2003). Characteristics of problem-based learning. International Journal of Engineering Education, 19(5), 657-662.

De Graaff, E., \& Cowdroy, R. (1997). Theory and practice of educational innovation through introduction of problem-based learning in architecture. International Journal of Engineering Education, 13(3), 166-174.

Dehkordi, A. H., \& Heydarnejad, M. S. (2008a). The effects of problem-based learning and lecturing on the development of Iranian nursing students' critical thinking. Pak J Med Sci, 24(5), 740-743.

Dehkordi, A. H., \& Heydarnejad, M. S. (2008b). The impact of problem-based learning and lecturing on the behavior and attitudes of Iranian nursing students. Dan Med Bull, 55(4), 224-226.

Du, X.-Y. (2006). Gendered practices of constructing an engineering identity in a problem-based learning environment. European Journal of Engineering Education, 31(01), 35-42. DOI:10.1080/03043790500430185

Duch, B. J., Groh, S. E., \& Allen, D. E. (2001a). The power of problem-based learning: A practical" how to" for teaching undergraduate courses in any discipline: Stylus Publishing, LLC.

Duch, B. J., Groh, S. E., \& Allen, D. E. (2001b). Why problem-based learning. The power of problem-based learning, 3-11.

Duplass, J. A., \& Ziedler, D. L. (2002). Critical thinking and logical argument. Social Education, 66(5), M10-M10.

Duron, R., Limbach, B., \& Waugh, W. (2006). Critical thinking framework for any discipline. International Journal of Teaching and Learning in Higher Education, 17(2), 160-166.

Edu, D., Ayang, E., \& Idaka, I. (2012). Evaluation of instructional methods and aptitude effects on the psychomotor performance in basic electricity among technical students in southern educational zone, cross river state, nigeria. American International Journal of Contemporary Research, 2(2), 117-123.

Egbo, B. (2011). Teacher capacity building and effective teaching and learning: a seamless connection. Mediterranean Journal of Social Sciences, 2(5), 11-17.

Eke, F. C. (2011). Preparing Today's Youth for the Changing World of Technology: The Role of Technical Education Teachers. Mediterranean Journal of Social Sciences, 71.

Evensen, D. H., \& Hmelo-Silver, C. E. (2000). Problem-based learning: A research perspective on learning interactions: Routledge.

Fani, T. (2011). Overcoming Barriers to Teaching Critical Thinking. Paper presented at the 1st international conference on the Future of Education, Florence, Italy, June.

Felder, R. M., \& Brent, R. (2003). Designing and teaching courses to satisfy the ABET engineering criteria. Journal of Engineering Education, 92(1), 7-25. DOI: 10.1002/j.2168-9830.2003.tb00734.x

Garba, A. S. (2010). Refocusing education system towards entrepreneurship development in Nigeria: a tool for poverty eradication. European Journal of social sciences, 15(1), 140-150.

Goddard, M. (2002). What do we do with these computers? Reflections on technology in the classroom. Journal of Research on Technology in Education, 35(1), 19-26. DOI:10.1080/15391523.2002.10782367

Goold, A., \& Augar, N. (2009). Using virtual meeting spaces for work integrated learning. Proceedings Ascilite Auckland, 367-371.

Gürses, A., Açıkyıldız, M., Doğar, Ç., \& Sözbilir, M. (2007). An investigation into the effectiveness of problem-based learning in a physical chemistry laboratory course. Research in Science \& Technological Education, 25(1), 99-113. D0I:10.1080/026351 40601053641

Halpern, D. F. (1998). Teaching critical thinking for transfer across domains: Disposition, skills, structure training, and metacognitive monitoring. American Psychologist, 53(4), 449. http://psycnet.apa.org/doi/10.1037/0003-066X.53.4.449 
Halpern, D. F. (1999). Teaching for critical thinking: Helping college students develop the skills and dispositions of a critical thinker. New directions for teaching and learning, 1999(80), 69-74. DOI: 10.1002/tl.8005

Halpern, D. F. (2002). Thought and knowledge: An introduction to critical thinking: Routledge.

Hemming, H. E. (2000). Encouraging critical thinking:" But... what does that mean?". McGill Journal of Education, 35(2), 173.

Hmelo, C. E., \& Evensen, D. H. (2000). Problem-based learning: Gaining insights on learning interactions through multiple methods of inquiry. Problem-based learning: A research perspective on learning interactions, 1-16.

Hung, W., Jonassen, D. H., \& Liu, R. (2008). Problem-based learning. Handbook of research on educational communications and technology, 3, 485-506.

Inti, M. M., Latib, A. B. A., \& Rufai, A. An Appraisal of Technical Skills Possessed by Technical College Auto-Mechanics Graduates in Nigeria.

Isah Usman, D., Celement, C. K., \& Raihan, M. A. (2013). A Study of the Problems for Development of Technical and Vocational Education in Katsina State, Nigeria.

Ismail, R., Yussof, I., \& Sieng, L. W. (2011). Employers' perceptions on graduates in Malaysian services sector. International Business Management, 5(3), 184-193. DOI: 10.3923/ibm.2011.184.193

Iwaoka, W. T., Li, Y., \& Rhee, W. Y. (2010). Measuring gains in critical thinking in food science and human nutrition courses: The Cornell Critical Thinking Test, problem-based learning activities, and student journal entries. Journal of Food Science Education, 9(3), 68-75. doi: 10.1111/j.1541-4329.2010.00100.x

Kasai, R., Sugimoto, K., \& Uchiyama, Y. (2006). The Effect of Problem Based Learning on Physics Therapy Education: A comparison of the short term educational effect between PBL and lecture based educational approaches. Rigakuryoho kagaku, 21(2), $143-150$.

Kennedy, O. O. (2011). Reappraising the Work Skill Requirements for Building Technology Education in Senior Secondary School for Optimum Performance in Nigeria. International Journal of Academic Research in Business and Social Sciences, 1(3), 24.

Kerka, S. (1992). Higher order thinking skills in vocational education: ERIC Clearinghouse.

Kjærsdam, F. (1994). Tomorrows Engineering Education. European Journal of Engineering Education.

Kolmos, A. (1996). Reflections on project work and problem-based learning. European Journal of Engineering Education, 21(2), 141148. DOI:10.1080/03043799608923397

Kolmos, A. (1999). Progression of collaborative skills. Paper presented at the Themes and Variations in Pbl, Vol. 1: Refereed Proceedings of the 1999 Bi-ennial Pbl, Conference, July 7-10, 1999, Montreal, Canada.

Kolmos, A. (2002). Facilitating change to a problem-based model. International Journal for Academic Development, 7(1), 63-74. DOI:10.1080/13601440210156484

Kolmos, A. (2010). Premises for Changing to PBL. International Journal for the Scholarship of Teaching and Learning, 4(1), 4. DOI: http://dx.doi.org/10.20429/ijsotl.2010.040104

Kolmos, A., Kuru, S., Hansen, H., Eskil, T., Podesta, L., Fink, F., . . Soylu, A. (2007). Problem Based Learnig.

Kuhn, D. (1999). A developmental model of critical thinking. Educational Researcher, 28(2), 16-46. doi: 10.3102/0013189X028002016

Kuhn, D. (2000). Metacognitive development. Current directions in psychological science, 9(5), 178-181. doi: 10.1111/1467-8721.00088

Kumar, M., \& Natarajan, U. (2007). A problem-based learning model: Showcasing an educational paradigm shift. The Curriculum Journal, 18(1), 89-102. DOI:10.1080/09585170701292216

Leikin, R. (2009). Exploring mathematical creativity using multiple solution tasks. Creativity in mathematics and the education of gifted students, 129-145.

Major, C. H., \& Palmer, B. (2001). Assessing the effectiveness of problem-based learning in higher education: Lessons from the literature. Academic exchange quarterly, 5(1), 4-9.

Mansur, D., Kayastha, S., Makaju, R., \& Dongol, M. (2014). Problem based learning in medical education. Kathmandu University medical journal, 10(4), 78-82. DOI: http://dx.doi.org/10.3126/kumj.v10i4.11002

Mantri, A. (2014). Working towards a scalable model of problem-based learning instruction in undergraduate engineering education. European Journal of Engineering Education, 39(3), 282-299. DOI:10.1080/03043797.2013.858106

Mantri, A., Dutt, S., Gupta, J., \& Chitkara, M. (2009). Using PBL to deliver course in Digital Electronics. Advances in Engineering Education, 1(4), 1-17.

Margwa, R., Onu, J., Jalo, J., \& Dire, B. (2015). MRP.

Marin, L. M., \& Halpern, D. F. (2011). Pedagogy for developing critical thinking in adolescents: Explicit instruction produces greatest gains. Thinking Skills and Creativity, 6(1), 1-13. http://dx.doi.org/10.1016/j.tsc.2010.08.002

Martin, L., West, J., \& Bill, K. (2008). Incorporating problem-based learning strategies to develop learner autonomy and employability skills in sports science undergraduates. Journal of Hospitality, Leisure, Sports and Tourism Education (Pre-2012), 7(1), 18. DOI:10.3794/johlste. 71.169

Masek, A. (2012). The effects of problem based learning on knowledge acquisition, critical thinking, and intrinsic motivation of electrical engineering students. Universiti Tun Hussein Onn Malaysia.

Masek, A., \& Yamin, S. (2012). The impact of instructional methods on critical thinking: a comparison of problem-based learning and conventional approach in Engineering education. ISRN Education, 2012. doi:10.5402/2012/759241

Matthews, B. (2004). The Effects of Direct and Problem-based Learning Instruction in an Undergraduate Introductory Engineering Graphics Course. http://www.lib.ncsu.edu/resolver/1840.16/4584

Miri, B., David, B.-C., \& Uri, Z. (2007). Purposely teaching for the promotion of higher-order thinking skills: A case of critical thinking. Research in science education, 37(4), 353-369. DOI:10.1007/s11165-006-9029-2 
Mohammed Lame, S., Yusoff, W., \& Fauziah, W. (2013). The perception of students towards entrepreneurship courses: an empirical study of Nigerian polytechnics students.

Morales-Mann, E. T., \& Kaitell, C. A. (2001). Problem-based learning in a new Canadian curriculum. Journal of advanced nursing, 33(1), 13-19. DOI: 10.1046/j.1365-2648.2001.01633.x

Mossuto, M. (2009). Problem-Based Learning: Student Engagement, Learning and Contextualized Problem-Solving. Occasional Paper. National Centre for Vocational Education Research (NCVER).

Inix, MuJ. W. (2012). Thinking critically about critical thinking. Educational Philosophy and Theory, 44(5), 464-479. DOI: 10.1111/j.14695812.2010.00673.x

Myers, S. C. (2008). Problem Based Learning in an Applied Econometric Curriculum. Paper presented at the Poster Session, Teaching Ideas and Projects, Allied Social Science Association Meetings, New Orleans.

Noordin, M. K., Nasir, A., Ali, D. F., \& Nordin, M. S. (2011). Problem-Based Learning (PBL) and Project-Based Learning (PjBL) in engineering education: a comparison. Proceedings of the IETEC, 11.

Norris, S. P. (1985). Synthesis of research on critical thinking. Educational leadership, 42(8), 40-45.

Norris, S. P. (1989). Can we test validly for critical thinking? Educational Researcher, 18(9), 21-26. doi: 10.3102/0013189X018009021

Onu, A. (2013). Stimulating Entrepreneurship in Educational Institutions In Nigeria. European Scientific Journal, 9(25).

Paul, R., \& Scriven, M. (2007). Defining critical thinking. Retrieved March, 14, 2008.

Pease, M. A., \& Kuhn, D. (2011). Experimental analysis of the effective components of problem-based learning. Science Education, 95(1), 57-86. DOI: $10.1002 /$ sce.20412

Prince, M. J., \& Felder, R. M. (2006). Inductive teaching and learning methods: Definitions, comparisons, and research bases. Journal of Engineering Education, 95(2), 123-138. DOI: 10.1002/j.2168-9830.2006.tb00884.x.

Prince, M. J., \& Felder, R. M. (2009). Inductive Teaching and Learning Methods. Definitions, Comparisons, and Research Bases. Research in Higher Education of Engineering, 3, 005.

Profetto-McGrath, J. (2005). Critical thinking and evidence-based practice. Journal of Professional Nursing, 21(6), 364-371. doi:10.1016/j.profnurs.2005.10.002.

Saraoglu, H., Yobaccio, E., \& Louton, D. (2000). Teaching Dynamic Processes in Finance: How Can We Prepare Students for an Age of Rapid and Continual Chance?

Savery, J. R. (2015). Overview of problem-based learning: Definitions and distinctions. Essential Readings in Problem-Based Learning: Exploring and Extending the Legacy of Howard S. Barrows, 5-15. : http://dx.doi.org/10.7771/1541-5015.1002.

Savery, J. R., Strobel, J., van Barneveld, A., English, M. C., Kitsantas, A., Hmelo-Silver, C. E., . . Dole, S. (2006). Interdisciplinary Journal of Problem-based Learning. Overview of Problem-based Learning: Definitions and Distinctions" by John R. Savery. http://dx.doi.org/10.7771/1541-5015.1002.

Savin-Baden, M. (2000). Problem-Based Learning In Higher Education: Untold Stories: Untold Stories: McGraw-Hill Education (UK).

Savin-Baden, M. (2003). Facilitating problem-based learning: McGraw-Hill Education (UK).

Şendağ, S., \& Odabaşı, H. F. (2009). Effects of an online problem based learning course on content knowledge acquisition and critical thinking skills. Computers \& Education, 53(1), 132-141. doi:10.1016/j.compedu.2009.01.008.

Shakirova, D. (2007). Technology for the shaping of college students' and upper-grade students' critical thinking. Russian Education \& Society, 49(9), 42-52. DOI 10.2753/RES1060-9393490905.

Shinde, V. (2011). Relevance of the problem and project based learning (PBL) to the Indian engineering education. PBL across the disciplines: Research into best practice, 489-502.

Shinde, V., \& Inamdar, S. (2014). Design of Course Level Project Based Learning Models for an Indian Engineering Institute: Institut for Planlægning, Aalborg Universitet.

Shinde, V. V., \& Inamdar, S. (2013). Problem Based Learning (PBL) for engineering education in India: Need and recommendations. Wireless personal communications, 69(3), 1097-1105. DOl:10.1007/s11277-013-1069-0.

Snyder, L. G., \& Snyder, M. J. (2008). Teaching critical thinking and problem solving skills. The Journal of Research in Business Education, 50(2), 90.

Spendlove, D. (2008). Creativity in education: A review. Design and Technology Education: An International Journal, 10(2).

Stewart, J., Cartier, J. L., \& Passmore, C. M. (2005). Developing understanding through model-based inquiry. How students learn, 515565.

Tan, O.-S., Chye, S., \& Teo, C.-T. (2009). Problem-based learning and creativity: A review of the literature. Problem-based learning and creativity, 15-38.

Ten Dam, G., \& Volman, M. (2004). Critical thinking as a citizenship competence: teaching strategies. Learning and instruction, 14(4), 359-379. doi:10.1016/j.learninstruc.2004.01.005.

Tiwari, A., Lai, P., So, M., \& Yuen, K. (2006). A comparison of the effects of problem-based learning and lecturing on the development of students' critical thinking. Medical education, 40(6), 547-554. DOI: 10.1111/j.1365-2929.2006.02481.x

Twiname, L. J., \& Gibb, J. (2012). Encouraging divergent thinking in HRM studies through use of project management case studies. Journal of Project, Program \& Portfolio Management, 2(2), 54-65.

Udofia, A., Ekpo, A., Nsa, E., \& Akpan, E. (2012). Instructional variables and students' acquisition of employable skills in vocational education in Nigerian technical colleges. Scholarly Journal of Education, 1(2), 13-19. Doi:10.5901/mjss.2012.v3n14p118.

Umunadi, E. K. (2012). Education Graduate Skill Development as Perceived by Employers in Institutions and Industries in Delta Sta. African Research Review, 6(2), 150-161. DOI: http://dx.doi.org/10.4314/afrrev.v6i2.13. 
Uwaifo, V. O. (2009). Industrializing the Nigerian society through creative skill acquisition vocational and technical education programme. International NGO Journal, 4(4), 142-145.

Wang, J., Fong, Y. C., \& Alwis, W. (2005). Developing professionalism in engineering students using problem based learning. Paper presented at the Proc. Regional Conference on Engineering Education RCEE.

Wang, Q., Woo, H. L., \& Zhao, J. (2009). Investigating critical thinking and knowledge construction in an interactive learning environment. Interactive learning environments, 17(1), 95-104. DOI:10.1080/10494820701706320.

Wong, K. K. H., \& Day, J. R. (2009). A comparative study of problem-based and lecture-based learning in junior secondary school science. Research in science education, 39(5), 625-642. DOI:10.1007/s11165-008-9096-7.

Wong, M. S. (2007). A prospective study on the development of critical thinking skills for student prosthetists and orthotists in Hong Kong. Prosthetics and orthotics international, 31(2), 138-146. DOI:10.1080/03093640600983931.

Xiuping, Z. (2002). The combination of traditional teaching method and problem based learning. The China Papers, 1(1), 30-36.

YILMAZ, S. (2013). Teaching for Critical Thinking: Helping College Students Develop the Skills and Dispositions of a Critical Thinker/Eleştirel Düşüncenin Öğretilmesi. Tarih Kültür ve Sanat Araştırmaları Dergisi, 2(1), 414-420. DOI: 10.7596/taksad. v2i1.191.

Young, J., \& Chapman, E. (2010). Generic competency frameworks: a brief historical overview. Education Research and Perspectives, $37(1), 1$.

Zhang, G. (2002). Using problem based learning and cooperative group learning in teaching instrumental analysis. The China Papers, 1 , 4-8.

Zhou, C. (2012). Integrating creativity training into problem and project-based learning curriculum in engineering education. European Journal of Engineering Education, 37(5), 488-499. DOI:10.1080/03043797.2012.714357.

Zhou, Q., Huang, Q., \& Tian, H. (2013). Developing Students' Critical Thinking Skills by Task-Based Learning in Chemistry Experiment Teaching. Creative Education, 4(12), 40. DOl:http://dx.doi.org/10.4236/ce.2013.412A1006

ZOLLER, U. (2001). Alternative assessment as (critical) means of facilitating HOCS-promoting teaching and learning in chemistry education. Chemistry Education Research and Practice, 2(1), 9-17. DOI: 10.1039/B1RP90004H

Zoller, U., Ben-Chaim, D., Ron, S., Pentimalli, R., Scolastica, S., Chiara, M. S., \& Borsese, A. (2000). The disposition toward critical thinking of high school and university science students: an interintra Israeli-Italian Study. International Journal of Science Education, 22(6), 571-582. DOI:10.1080/095006900289679.

Zoller, U., \& Pushkin, D. (2007). Matching Higher-Order Cognitive Skills (HOCS) promotion goals with problem-based laboratory practice in a freshman organic chemistry course. Chemistry Education Research and Practice, 8(2), 153-171. DOI: 10.1039/B6RP900 $28 \mathrm{C}$. 